\title{
THERMAL PROCESSES IN HUMAN SKIN UPON IRRADIATION BY LASER PULSES
}

\author{
N.G. Kokodii \\ Dr. Sci. (Phys.-Math.), Prof. \\ Department of Quantum Radio-Physics \\ V.N. Karazin Kharkov National University \\ 4 Svobody Sq., Kharkiv, 61022, Ukraine \\ tel: +38 (057) 707-51-57 \\ e-mail: kokodiyng@gmail.com \\ ORCID 0000-0003-1325-4563
}

\author{
A.M. Korobov \\ Cand. Sci. (Phys.-Math.), Head of the laboratory \\ Science and Research Laboratory of Quantum Biology \\ and Quantum Medicine \\ V.N. Karazin Kharkiv National University \\ 6 Svobody Sq., Kharkiv, 61022, Ukraine \\ tel: +38 (057) 707-51-91 \\ e-mail:amkorobov@karazin.ua \\ ORCID 0000-0001-8237-7159
}

\author{
V.A. Timaniuk \\ Cand. Sci. (Phys.-Math.), Prof. \\ Department of Physics \\ National University of Pharmacy \\ 53 Pushkinsraya St., Kharkiv, 61002, Ukraine \\ tel: +38 (057) 771-81-59 \\ e-mail:physics@nuph.edu \\ ORCID 0000-0003-0689-6074
}

The mathematical model of the process of heating the surface of the skin and its inner layers of short laser pulses. Duration of pulses is much less then time setting temperature in the body. It is using the solution of the equation of thermal conductivity for semi-infinity of the body when it is heated by flow of the electromagnetic radiation. Heat exchange with the outside space is not happening for the duration of a pulse, so the surface of the body can be considered isolated. The body temperature is rising almost linear. After the end of the pulse it decreases slowly (thermal time constant is 20 min approximately).

By heating a series of pulses the temperature increases in the same way as by heating of continuous radiation.

It is calculated the increase temperature of body by heating pulses $10 \mathrm{~ms}$, am-plitude $10 \mathrm{~W}$, period of $50 \mathrm{~ms}$. The average radiated power is $2 \mathrm{~W}$. The temperature of body within $5 \mathrm{~s}$ rises to $300^{\circ} \mathrm{C}$.

Key words: irradiation by laser pulses, human skin, thermal processes.

\section{ТЕПЛОВІ ПРОЦЕСИ В ШКІРІ ЛЮДИНИ ПІД ЧАС ОПРОМІНЕННЯ ЛАЗЕРНИМИ ІМПУЛЬСАМИ}

\author{
М.Г. Кокодій ${ }^{1,2}$, В.О. Тіманюк ${ }^{2}$, А.М. Коробов ${ }^{1}$ \\ ${ }^{1}$ Харківський національний університет імені В. Н. Каразіна, м. Харків, Украӥна; \\ ${ }^{2}$ Національний фармацевтичний університет, м. Харків, Украӥна
}

Запропоновано математичну модель процесу нагрівання поверхні шкіри і її внутрішніх шарів короткими лазерними імпульсами. Тривалість імпульсів набагато менше часу встановлення температури. Було використане розв'язання рівняння теплопровідності для напівбескінечного тіла при нагріванні потіком електромагнітного випромінювання. За час дії імпульсу теплообмін з зовнішнім середовищем не відбувається, тому поверхня тіла може вважатися теплоізольованою. Температура тіла зростає майже за лінійним законом. Після закінчення імпульсу температура повільно знижується (теплова постійна часу становить приблизно 20 хв.).

При нагріванні серією імпульсів температура тіла збільшується так само, як при нагріванні безперервним випромінюванням.

Обчислено підвищення температури тіла під час нагрівання імпульсами тривалістю 10 мс кожний, амплітудою 10 Вт, $з$ періодом 50 мс. Середня потужність складає 2 Вт. Температура тіла протягом 5 с піднімається до $300^{\circ} \mathrm{C}$.

Ключові слова: імпульсне лазерне випромінювання, шкіра людини, теплові процеси. 


\title{
ТЕПЛОВЫЕ ПРОЦЕССЫ В КОЖЕ ЧЕЛОВЕКА ПРИ ОБЛУЧЕНИИ ЛАЗЕРНЫМИ ИМПУЛЬСАМИ
}

\author{
Н.Г. Кокодий ${ }^{1,2}$, В.А. Тиманюк ${ }^{2}$, А.М. Коробов ${ }^{1}$ \\ ${ }^{1}$ Харьковский национальный университет имени В.Н.Каразина, г. Харьков, Украина \\ ${ }^{2}$ Национальный фармацевтический университет, г. Харьков, Украина
}

Предложена математическая модель процесса нагрева поверхности кожи и ее внутренних слоев короткими лазерными импульсами, длительность которых намного меньше времени установления температуры в теле. Используется решение уравнения теплопроводности для полубесконечного тела при нагреве потоком электромагнитного излучения. За время действия импульса теплооб-мен с внешним пространством не происходит, поэтому поверхность тела можно считать изолированной. Температура тела растет почти по линейному закону. После окончания импульса она медленно уменьшается (тепловая постоянная времени около 20 мин).

При нагреве серией импульсов температура увеличивается так же, как при нагреве непрерывным излучением.

Вычислен рост температуры тела при нагреве импульсами длительностью 10 мс, амплитудой 10 Вт, идущих с периодом 50 мс. Средняя мощность излучения 2 Вт. Температура тела в течение 5 с повышается до $300^{\circ} \mathrm{C}$.

Ключевые слова: импульсное лазерное облучение, кожа человека, тепловые процессы.

\section{Introduction}

Research of thermal processes occurring under the action of laser radiation on humans, given the opportunity to develop new therapies for many diseases. However, the complexity of the object of exposure (skin, subcutaneous tissues, circulatory organs) cause was a need for further study of phenomena that occur at the same time. Theoretical and experimental research in this direction are made in the Laboratory of Quantum Biology and Quantum Medicine KNU. In works [1, 2], which were presented at the conferences "Lasers in medicine and biology", investigates the thermal processes when exposed to human skin and continuous optical radiation pulses, the duration of which is more time setting the temperature in the object of influence.

In this work the calculations of the heating of the skin and subcutaneous layers in the case of short optical radiation pulses.

\section{Mathematical model}

Mathematical model of the structure of the skin adopted is the same as in works [1, 2]. It is shown in Fig. 1 and corresponds to the model proposed in the paper [3]. In the skin there are three parts. The upper part is the epidermis is a multilayered epithelium, the outer layer which is the stratum cornea. The bottom layer of the epidermis rests on the basement membrane. It contains melanocytes cells that protect skin from the harmful effects of sunlight. The inner skin is the dermis has a thickness of from $0.5 \mathrm{~mm}$ to $5 \mathrm{~mm}$ and in it are the blood vessels.

The thickness of epidermis is approximately equal to $0.06 \mathrm{~mm}$. The fraction of energy absorbed in this layer is small, so the presence of a layer can not be ignored, and to consider the fabric of a homogeneous body. Therefore, the problem of heating a semi-infinite body by optical radiation penetrating into it in some depth.
The penetration depth of radiation in the ultraviolet region of a few micrometers, in a green about $1 \mathrm{~mm}$, in the red region of the depth of penetration increased to 20-30 mm. Short-wave infrared radiation with wavelengths less than $1.5 \mu \mathrm{m}$ penetrates to $30-70 \mathrm{~mm}$.

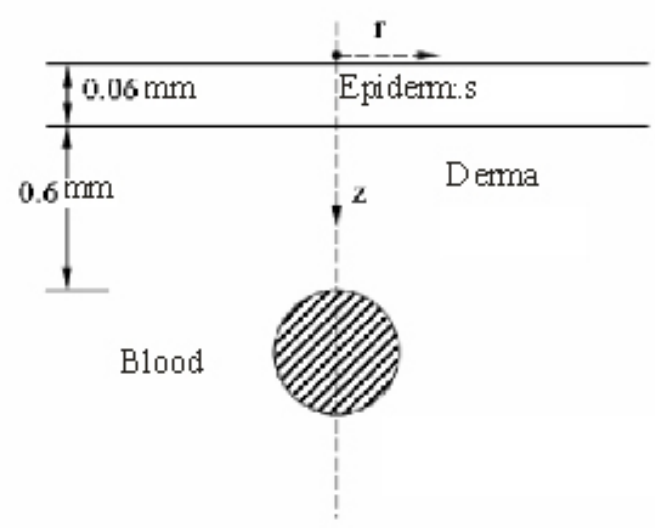

Fig. 1. Model of the structure of the skin

The change of radiation intensity along the z-axis (into the body) is described by the Bouguer law:

$$
I(z)=I_{0} e^{-\frac{z}{\delta}}
$$

where $\delta$ - the penetration depth of the radiation level $1 / e$.

Volume density of heat sources is determined by the formula:

$$
S(z, t)=\frac{I_{0}}{\delta} e^{-\frac{z}{\delta}} .
$$


The task is described in works $[1,2]$, took into account the removal of heat deep into the body, the tissue conductivity and blood flow. It was shown that when heating of the skin continuous emission temperature is set slowly for about $20 \mathrm{~min}$. So when heated with short pulses, the duration of which is much less time setting temperature, the withdrawal of heat from the heated region can not ignore this area be treated as insulated. The heat conduction equation in this case looks like this:

$$
\frac{\partial^{2} T(z, t)}{\partial z^{2}}-\frac{1}{a} \frac{\partial T(z, t)}{\partial t}=-\frac{S(z, t)}{k} .
$$

It differs from the equation in work [1] lack of the right part of the expression describing the dissipation of heat by blood flow.

Initial and boundary conditions remain the same:

$$
T(z, 0)=0, \quad \frac{\partial T(0, t)}{\partial z}=0, T(\infty, t)=0
$$

They mean the absence of heat exchange between the heated surface and the environment and zero temperature in the depth of the body.

In the calculations we used the following data about the thermophysical parameters of the skin [3]: $k=0.5 \mathrm{~W} /(\mathrm{m} \mathrm{K}), c=3500 \mathrm{~J} /(\mathrm{kg} \mathrm{K}), \rho=1100 \mathrm{~kg} / \mathrm{m}^{3}$.

The parameters of laser radiation were adopted as follows: pulse power $P_{0}=30 \mathrm{~W}$; pulse duration $t_{p}=10 \mathrm{~ms}$; repetition period of pulses $T=20 . . .50 \mathrm{~ms}$; beam diameter $D=1 \mathrm{~mm}$; the depth of penetration of the radiation in the level $1 / e(d=10 \mathrm{~mm})$.

The solution of equation (1) looks like this:

$$
T(z, t)=\left\{\begin{array}{l}
T_{0}(z, t) \quad \text { if } \quad 0 \leq t \leq t_{p} \\
T_{0}(z, t)-T_{0}\left(z, t-t_{p}\right) \text { if } \quad t \leq t_{p}
\end{array} .\right.
$$

where

$$
T_{0}(z, t)=\frac{P_{0} \delta}{k S}\left\{\frac{2 \sqrt{a t}}{\delta} \operatorname{ierfc}\left(\frac{z}{2 \sqrt{a t}}\right)-e^{-\frac{z}{\delta}}+\frac{1}{2} e^{\frac{a t}{\delta^{2}}}\left[e^{-\frac{z}{\delta}} \operatorname{erfc}\left(\frac{\sqrt{a t}}{\delta}-\frac{z}{2 \sqrt{a t}}\right)+e^{\frac{z}{\delta}} \operatorname{erfc}\left(\frac{\sqrt{a t}}{\delta}+\frac{z}{2 \sqrt{a t}}\right)\right]\right\} .
$$

$\operatorname{erfc}(x)$ is the additional error function, $\operatorname{ierfc}(x)=\frac{1}{\sqrt{\pi}} e^{-x^{2}}-x \operatorname{erfc}(x)$ is integral of the additional error functions, $a=\frac{k}{c \rho}$ is thermal diffusivity coefficient of the biological tissue, $S-$ cross sectional area of the beam.
The time course of temperature at different depths calculated by the formula (2) for a single pulse with the parameters specified above, shown in Fig. 2.

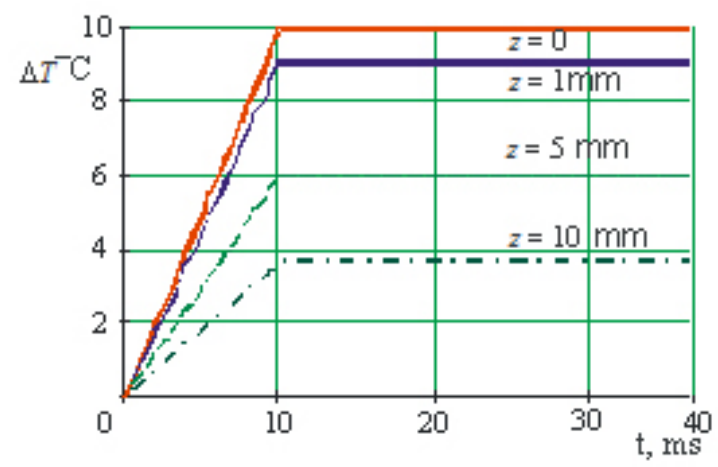

Fig. 2. The time course of temperature during heating of biological tissue by the radiation pulse

For the duration of the pulse $(10 \mathrm{~ms})$, the temperature increases almost linearly. In fact, it is the exponent with a time constant of $300 \mathrm{~s}$. However, on a very small initial part it differs little from a straight line. After the pulse occurs, the cooling fabric is also exponential. On the chart the decrease in temperature imperceptible, as it occurs slowly (with a time constant of $300 \mathrm{~s}$ ).

As for the duration of the pulse, the heated heat exchange area with the environment does not occur; the maximum heating temperature is determined by the absorbed energy and heat capacity of the heated volume. It can be estimated by a simple formula:

$$
\Delta T_{\max }=\frac{E}{m c}=\frac{P_{0} t_{p}}{c \rho \delta S},
$$

where $E$-pulse energy, $P_{0}-$ pulse power, $t_{p}$ - pulse duration, $S-$ cross sectional area of the beam, $c-$ specific heat, $\rho$ - density.

In Fig. 3 shows the temperature distribution along the $\mathrm{z}$ coordinate is the depth in tissue. His profile fits the profile distribution of radiation intensity according

to the law $e^{-\frac{z}{\delta}}$. The radius of the radiation intensity and the temperature in our problem is constant.

The temperature and its distribution in space is determined only by pulse energy. It is independent of pulse duration. Even for $t_{p}=1 \mathrm{~s}$ the graphics $T(z, t)$ are the same as in Fig. 2 and 3. It is due what heat exchange to external volume is absent.

By heating the target with a series of pulses temperature at the end of each pulse increases by a certain 


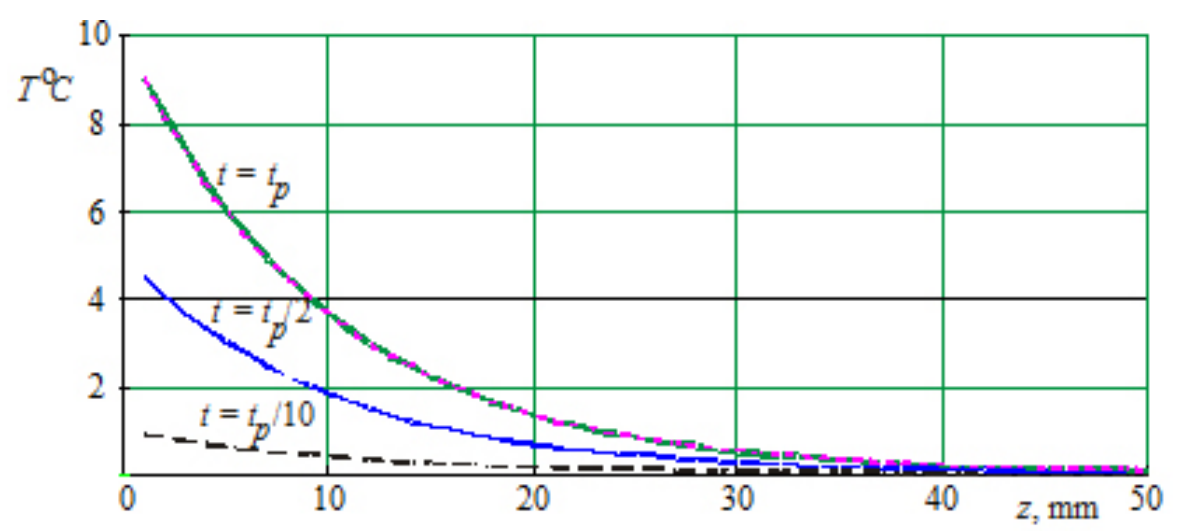

Fig. 3. Temperature distribution in biological tissue at depth

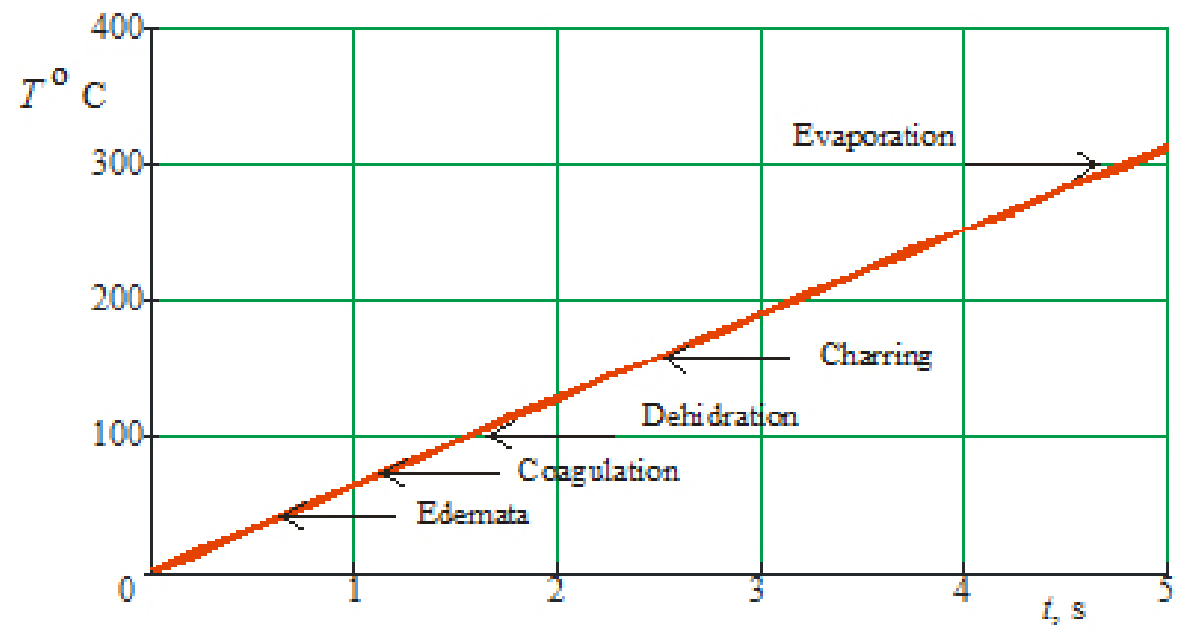

Fig. 4. Heating of biological tissue with a pulsed radiation (average power is $2 \mathrm{~W}$ )

amount $\Delta T$, while the exposure time is much less than the thermal time constant $\tau$. Therefore, the heating rate can be adjusted by changing the duty cycle (the repetition period of pulses). This changes the average radiation power.

In Fig. 4 shows the course of heating of biological tissue to pulsed-modulated radiation with an average power of $2 \mathrm{~W}$ (pulse duration is $10 \mathrm{~ms}$, pulse power is $10 \mathrm{~W}$, the period is $50 \mathrm{~ms}$ ). Such power is enough for a few seconds the temperature of the tissue increased to $300 \mathrm{oC}$ by increasing the duty cycle twice the average power is reduced twice. This way you can set the wattage at which the temperature of the surface layers of tissue during, for example, $1 \mathrm{~s}$ will rise to the temperature required for the doctor's work.

\section{Conclusions}

1. The temperature of the biological tissue when it is heated single laser pulse is determined by the pulse energy and the heated volume (beam diameter and penetration depth of radiation in tissue). The duration of the radiation pulse is not a function.
2. When heating of tissue pulse-modulated laser radiation, the degree of heat it is convenient to regulate the change of the duty cycle (the repetition period of pulses at a constant pulse duration of radiation).

\section{References}

1. Kokodiy NG, Korobov AM, Timaniuk VA. Thermal processes in the human skin irradiated with LEDs. Materialyi XLV Mezhdunar. nauch.-prakt. konf. Primenenie lazerov v meditsine i biologii [Proceedings of XLV International Sc. and Pract. Conf. Application of Lasers in Medicine and Biology]; 2016 Oct 6-8; Kharkiv-Bukovel. Kharkiv: Petrov V.V. Publ.; 2016; p. 124-8. (in Russian)

2. Kokodiy NG, Korobov AM, Timaniuk VA. Limit cases of exposure to human skin of optical radiation. aterialyi XLVI Mezhdunar. nauch.-prakt. konf. Primenenie lazerov v meditsine i biologii [Proceedings of XLVI International Sc. and Pract. Conf. Application of Lasers in Medicine and Biology]; 2017 May 25-27; Kharkiv. Kharkiv: Petrov V.V. Publ.; 2017; p. 166-8. (in Russian)

3. Pushkareva AE. Metodyi matematicheskogo modelirovaniya v optike biotkani: uchebnoe posobie [Methods of mathematical modeling in biotink optics: a manual]. St.Pb: St.PbSUITMO Publ.; 2008. 103 p. (in Russian) 